\title{
Inflasi dan Suku Bunga terhadap Return Saham Subsektor Perbankan Indeks KOMPAS100 2015 - 2019
}

\author{
Fransiskus Xaverius Nanna Sugiyanto ${ }^{1}$ \\ Fakultas Ekonomi \\ Universitas Pamulang, Indonesia
}

\author{
Shinta Ningtiyas Nazar ${ }^{2}$ \\ Fakultas Ekonomi \\ Universitas Pamulang, Indonesia
}

\author{
Kansas Syafrizal ${ }^{3}$ \\ Fakultas Ekonomi \\ Universitas Pamulang, Indonesia
}

Surel : aansugiyanto13@gmail.com

\section{ABSTRAK}

Hasil penelitian ini dibuktikan secara empiris inflasi dan suku bunga dan return saham subsektor perbankan pada indeks KOMPAS100. Peneliti menggunakan variabel kontrol berupa PER dan PBV. Penelitian ini berjenis penelitian kuantitatif yang data sekunder digunakan sebagai jenis data. Populasi adalah saham indeks KOMPAS100 2015-2019 dan menggunakan teknik purposive sampling sehingga diperoleh 9 saham subsektor perbankan dalam indeks KOMPAS100 2015-2019. Analisis regresi linier berg\&a diguanakan sebagai teknik analisis data. Variabel inflasi dan suku bunga secara simultan berpengaruh terhadap return saham dengan PER dan PBV sebagai variabel kontrol adalah hasil penelitian yang diperoleh. Variabel inflasi tidak dipengaruhi secara signifikan terhadap return saham. Variabel suku bunga dipengaruhi negatif signifikan terhadap return saham. PER dan PBV sebagai variabel kontrol tidak dipengaruhi secara signifikan terhadap return saham.

Kata Kunci: Inflasi; Suku Bunga; Return Saham; Indeks KOMPAS100.

\section{Inflation and Interest Rates on Stock Returns in the Banking Subsector KOMPAS100 Index 2015 - 2019}

\section{ABSTRACT}

The consider pointed to decide \& to demonstrate experimentally the impact of swelling \& intrigued rate on the stock return of the keeping money subsector stock within the KOMPAS100 record. Analyst utilized control factors, to be specific PER \& PBV. This sort of investigate classified as quantitative inquire about \& utilizing auxiliary information. The populace in this study are stocks within the KOMPAS100 record 2015-2019 \& utilized purposive testing strategy coming about 9 stocks of the keeping money subsector of KOMPAS100 list 2015-2019 as the test. The examination method utilized in this inquire about is numerous straight relapse. The comes about demonstrate that the expansion \& intrigued rate factors at the same time impact stock return with PER \& PBV as control factors. The expansion variable does not have a significant effect on stock returns. Intrigued rate variable incorporates a critical negative impact on stock returns. PER \& PBV as control factors have no critical impact on stock return.

Keywords: $\quad$ Inflation; Interests; Stock Return; Indeks KOMPAS100.

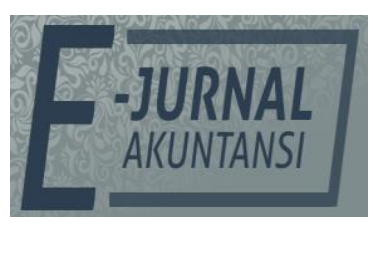

e-ISSN 2302-8556

Vol. 31 No. 6

Denpasar, Juni 2021

Hal. 1604-1614

DOI:

10.24843/EJA.2021.v31.i06.p20

PENGUTIPAN:

Sugiyanto, F.X.N., Nazar,

S.N., \& Syafrizal, K. (2021).

Inflasi dan Suku Bunga terhadap Return Saham

Subsektor Perbankan Indeks KOMPAS100 2015 - 2019. EJurnal Akuntansi, 31(6), 16041614

RIWAYAT ARTIKEL: Artikel Masuk: 15 Februari 2021 Artikel Diterima: 21 Juni 2021

Artikel dapat diakses : https://ojs.unud.ac.id/index.php/Akuntansi/index 


\section{PENDAHULUAN}

Perekonomian negara-negara di dunia terus berkembang. Negara maju dan negara berkembang melaui berbagai macam cara bersaing untuk terus memajukan perekonomian makro. Investasi adalah salah satu cara yang dilakukan melalui fasilitas pasar modal saham di Indonesia. Pasar modal melalui kedua fungsinya sebagai peranan yang penting dalam meingkatkan perekonomian suatu negara, perusahaan juga dapat memperoleh setoran pendapatan dari masyarakat dan sarana bagi masyarakat untuk berinvestasi pada instrumen keuangan (Saputra \& Wardoyo 2019).

Tujuan utama investor saham digunakan untuk mendapatkan return, yaitu besarnya tingkat pengembalian aktivitas investasi di pasar modal (Denziana, et al. 2015). Return yang akan diperoleh investor dapat dilihat dari saham perusahaan yang dibeli, dengan mempertimbangakan subsektor dan atau dengan melihat indeks saham. Subsektor perbankan adalah salah satu subsektor penting dalam perekonomian makro suatu Negara dan subsketor yang sering di rekomendasikan oleh analis fundamental dan teknikal lewat media online. Media bekerjasama dengan analis sekuritas untuk memberikan rekomendasi harian saham investasi jangka panjang maupun jangka pendek. Terdapat beberapa Indeks di BEI, indeks yang relevan dengan rekomendasi investasi saham di media adalah indeks KOMPAS100 yaitu hasil kerja sama BEI dan perusahaan Kompas Gramedia yang melihat pada 100 kinerja saham dengan kapitalisasi pasar besar dan likuiditas yang baik (Dwialesi \& Darmayanti, 2016). Tahun 2015-2019 merupakan tahun yang menarik bagi para investor karena terjadi fluktuasi return saham subsektor perbankan dalam indeks KOMPAS100.

Tabel 1. Fluktuasi Return Saham

\begin{tabular}{cc}
\hline Tahun & Return $(\%)$ \\
\hline 2015 & -3 \\
2016 & 16 \\
2017 & 16 \\
2018 & 3 \\
2019 & -8
\end{tabular}

Sumber: Data Penelitian, 2020

Tahun 2015 return memproyeksikan angka minus, artinya secara keseluruhan tidak ada keuntungan dari investasi subsektor perbankan pada indeks KOMPAS100. Tahun 2016 terjadi lonjakan return menjadi 16 persen dalam kurun waktu 1 (satu) tahun dan bertahan sampai dengan tahun 2017. Return saham mulai mengalami penurunan yang siginfikan di tahun 2018 mencapai angka 3 persen. Penurunan terus berlanjut di tahun 2019, lebih buruk dari tahun 2015 hingga mencapai -8 persen yang artinya terjadi capital loss atau return yang minus.

Investor perlu mencermati faktor-faktor apa saja yang menyebabkan terjadinya fluktuasi return tersebut. faktor makro ekonomi dan mikro ekonomi menjadi faktor pertimabangan yang harus diperhatikan oleh investor. Faktor makro ekonomi yang berpotensi mempengaruhi adalah inflasi dan suku bunga (Al-Abdallah 2017).

Inflasi dapat direpresentasikan melalui sebuah kondisi kondisi dan situasi pada harga barang mengalami kenaikan secara menyeluruh dalam periode 
tertentu (Iqmal \& Putra 2020). Inflasi yang terlalu tinggi merupakan sinyal negatif bagi perusahaan, sedangkan inflasi yang terlalu rendah membuat pertumbuhan ekonomi lamban kemudian harga saham bergerak lamban berdampak secara langsung kepada return saham (Suriyani \& Sudiartha 2018). Pada bank penurunan inflasi akan memberikan keuntungan secara langsung sehingga berdampak pada daya tarik investor terhadap saham yang kemudian mempengaruhi return saham (Wijayanti \& Sishadiyati 2020).

Suku bunga adalah faktor makro ekonomi yang dipengaruhi oleh return saham. Suku bunga merupakan bentuk kebijakan moneter Bank Indonesia (Afiyanti 2018). Ekspektasi nilai suku bunga di masa depan berperan penting sebagai masukan dalam menentukan investasi (Assagaf et al. 2019). Pada saat suku bunga rendah maka akan terjadi peningkatan aktivitas ekonomi dan investasi. Hal sebaliknya dijelaskan dalam penelitian Dewi \& Artini (2016) bahwa naiknya tingkat suku bunga memicu investor untuk menarik dananya dan berinvestasi pada subsektor perbankan dengan tingkat resiko yang lebih rendah dari saham.

Faktor fundamental dalam penelitian digunakan sebagai variabel berupa PER dan PBV. PER merupakan analisis perb\&ingan harga dan pendapatan perusahaan yang menggambarkan harga wajar saham (Novitasari 2017). PBV juga merupakan rasio pasar yang menilai harga wajar saham menggunakan harga saham dan nilai buku (Dwialesi \& Darmayanti, 2016). Angka PER dan PBV yang semakin besar men\&akan harga saham sudah tidak wajar atau mahal.

Aritrage Pricing Theory digunakan dalam penelitian sebagai bahan pertimbangan ketika mengkaji return saham dan faktor makro ekonomi, inflasi dan suku bunga (Gusni \& Riantani 2017). Inflasi dan suku bunga merupakan faktor makroekonomi yang memiliki keterkaitan satu sama lain. Kedua indikator erat kaitannya ketika dihubungkan aktivitas perusahaan, terkhusus subsektor perbankan. Kenaikan dan penurunan indikator-indikator tersebut mempengaruhi biaya aktivitas operasional yang dikeluarkan perusahaan dalam memberikan pelayanan atau produk, secara tidak langung berdampak pada keuangan perusahaan yang tersaji di laporan keuangan. Perubahan angka-angka pada laporan keuangan menjadi perhatian investor ketika akan melakukan investasi. Harga saham dipengaruhi oleh keputusan investasi yang kemudian berdampak pada perubahan return saham. Variabel makro ekonomi dipenagruhi oleh reurn saham, secara positif signifikan pada penelitian yang dilakukannya. Sejalan dengan Adnyana et al. (2019) ada keterkaitan antara variabel makro terhadap terhadap return saham.

$\mathrm{H}_{1}$ : Inflasi dan suku bunga berpengaruh terhadap return saham.

Inflasi akan meningkatkan pendapatan dan biaya perusahaan (Eldomiaty et al. 2019). Harga tinggi akan meningkatkan biaya produksi, sehingga perusahaan dapat menikmati kenaikan harga, profitabilitas perusahaan akan melemah. Jika keuntungan diperoleh oleh perusahaan kecil maka akan menyebabkan investor enggan menanamkan modalnya di perusahaan tersebut yang akan menyebabkan harga saham turun yang pada akhirnya akan mempengaruhi pendapatan saham yang diterima investor.

Penelitian yang dilakukan oleh Kurniasari et al. (2018) dan Jamaludin et al. (2017) menjelaskan adanya pengaruh negatif signifikan inflasi terhadap return saham. Penelitian Sangmi (2013), Al Oshaibat \& Majali (2016) dan penelitian Zaini 
et al. (2018) menjelaskan terdapat pengaruh positif antara inflasi dan return saham. Berlawanan dengan penelitian yang dilakukan Yunita \& Robiyanto (2018) dan Wiradharma \& Sudjarni (2016) yang menyebutkan bahwa inflasi tidak berpengaruh terhadap return saham.

$\mathrm{H}_{2}$ : Diduga inflasi berpengaruh terhadap return saham.

Beban bunga dan biaya modal dapat dinaikkan oleh suku bunga, sehingga laba perusahaan dapat diturunkan Eldomiaty et al. (2019). Tingkat pengembalian saham dapat menahan penurunan laba, karena diharapkan harga saham perseroan akan turun di pasar modal. Sebaliknya, jika keadaan seperti itu terjadi, masyarakat akan ingin lebih banyak menanamkan dananya di modal. pasar. Suku bunga yang lebih rendah, yang akan dicapai dengan meningkatkan pengembalian saham. Jika investor berinvestasi pada saham dengan tingkat suku bunga tinggi, investor akan kehilangan kesempatan untuk memperoleh keuntungan yang lebih tinggi. Investor cenderung berinvestasi pada saham di pasar modal, tetapi dengan mengorbankan kesempatan untuk memperoleh tingkat suku bunga kembali, jika tidak mereka akan terpengaruh oleh suku bunga Batas atas suku bunga rendah.

Bukti empiris mengenai pengaruh suku bunga dipengaruhi return saham dijelaskan melalui penelitian Nofitasari \& Kurniasih (2020) yang menjelaskan adanya pengaruh positif signifikan. Penelitian Yunita \& Robiyanto (2018) menjelaskan bahwa tidak ada keterkaitan antara suku bunga dipengaruhi oleh return saham. Hasil yang berbeda diungkap melalui peneltian Al-Abdallah (2017), Apriliany \& Effendi (2019), Siregar \& Sasongko (2016), Yusfiarto (2020) dan Balagobei (2017) yang menyampaikan adanya hubungan yang negatif signifikan. $\mathrm{H}_{3}$ : Diduga suku bunga berpengaruh terhadap return saham.

Penelitian dapat dilihat untuk menguji pengaruh Inflasi, Suku Bunga terhadap Return Saham dengan PER dan PBV sebagai variabel kontrol. Adapun keterkaitan antar faktor makroekonomi dan faktor fundamental terhadap return yang akan diteliti digambarkan sebagai berikut.

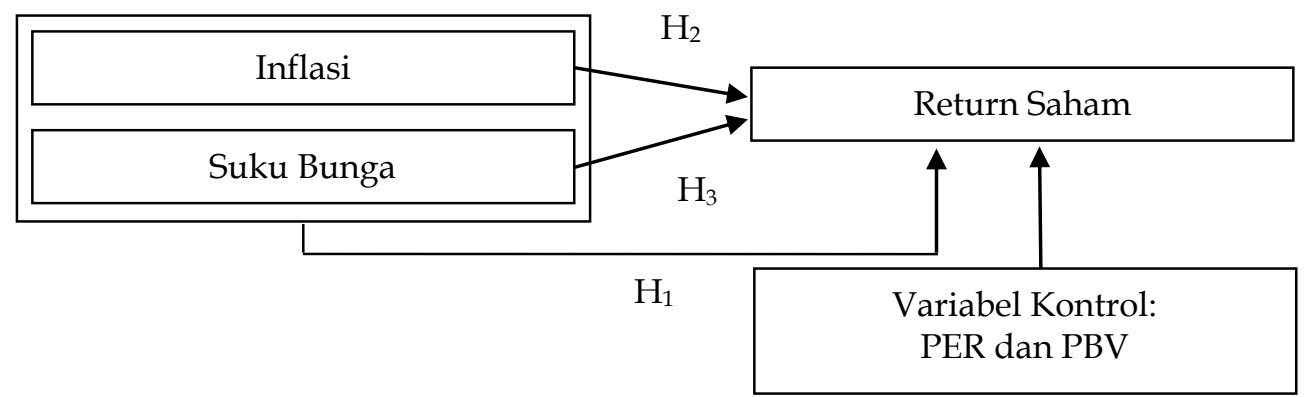

Gambar 1. Model Peneltian

Sumber: Data Penelitian, 2019

\section{METODE PENELITIAN}

Penelitian kuantitatif digunakan sebagai jenis penelitian dengan memperoleh data dalam bentuk digital yang diperoleh dari situs resmi instansi terkait di Indonesia melalui media internet. Penelitian ini menggunakan dua variabel independen yaitu inflasi dan suku bunga, satu variabel dependen yaitu return saham, dan dua variabel kontrol yaitu rasio harga terhadap pendapatan dan nilai aktiva bersih. 
Return saham sama dengan imbal hasil investor yang diperoleh atas aktivitas investasi. Hartono (2017).

$\mathrm{Rt}=\frac{\mathrm{Pt}-\mathrm{Pt}-1+\mathrm{D}_{\mathrm{t}}}{\mathrm{Pt}-1}$

Inflasi sama dengan Tren kenaikan harga produk secara keseluruhan Suriyani \& Sudiartha (2018).

$\operatorname{Inf}=\frac{\operatorname{IHKt}-\mathrm{IHK}(\mathrm{t}-1)}{\operatorname{IHK}(\mathrm{t}-1)}$

Suku bunga merupakan bentuk kebijakan bank sentral dalam hal Bank Indonesia. Suriyani \& Sudiartha (2018), Perhitungan suku bunga Tren kenaikan harga diperoleh dengan rata-rata persentase suku bunga tahunan dan suku bunga bulanan.

PER sama dengan rasio pasar perb\&ingan harga saham dan EPS sebagai tolak ukur kewajaran harga saham. PER dapat dirumuskan.

PER $=\frac{\text { Harga Saham }}{\text { EPS }}$

$\mathrm{PBV}=$ rasio perb\&ingan harga saham dengan nilai buku sebagai tolak ukur kewajaran harga saham. Novitasari (2017), PBV dapat dirumuskan.

$\mathrm{PBV}=\frac{\text { Current Price }}{\text { Book Value }}$.

Perusahaan yang menggunakan populasi untuk penelitian adalah perusahaan indeks KOMPAS100 yang diperoleh melalui teknologi pencatatan, dan merupakan sampel penelitian yang diperoleh melalui teknik purposive sampling yang menetapkan kondisi tertentu.

Penelitian ini menggunakan uji statistik deskriptif, uji normal, uji multikolinearitas, uji heteroskedastisitas, uji autokorelasi, uji koefisien determinasi, uji regresi linier berg\&a, uji $\mathrm{F}$ dan uji $\mathrm{t}$. Tes, didasarkan pada model regresi sebagai berikut.

$$
\mathrm{Y}=\alpha+\beta_{1} \mathrm{X}_{1}+\beta_{2} \mathrm{X}_{2}+\beta_{3} \mathrm{X}_{3}+\beta_{4} \mathrm{X}_{4}+\varepsilon
$$

Dimana:

$$
\begin{array}{ll}
\mathrm{Y} & =\text { Return Saham } \\
\mathrm{a} & =\text { Konstanta } \\
\beta & =\text { Koefisien regresi } \\
\mathrm{X}_{1} & =\text { Inflasi } \\
\mathrm{X}_{2} & =\text { Suku Bunga } \\
\mathrm{X}_{3} & =\text { Price Earning Ratio } \\
\mathrm{X}_{4} & =\text { Price to Book Value } \\
\varepsilon & =\text { Error }
\end{array}
$$

\section{HASIL DAN PEMBAHASAN}

Jenis penelitian ini adalah kuantitatif dengan menggunakan angka dan statistik untuk menentukan tujuan penelitian secara empiris. Data dalam bentuk digital dalam penelitian merupakan data penolong yang berkaitan dengan kebutuhan penelitian. Metode pengambilan sampel dalam penelitian ini menggunakan purposive sampling yang memenuhi ketentuan sebagai berikut.

\section{Tabel 2. Tabel Prosedur Pengambilan Sampel}




\begin{tabular}{llcc}
\hline \multicolumn{1}{c}{ Kriteria } & $\begin{array}{c}\text { Tidak Memenuhi } \\
\text { Kriteria }\end{array}$ & Memenuhi Kriteria \\
\hline $1 \quad$ Porusahaan dalam indeks & & 100 \\
2 & $\begin{array}{l}\text { KOMPAS100 } \\
\text { Perusahaan subsektor perbankan } \\
\text { dalam indeks KOMPAS100 periode }\end{array}$ & $(86)$ & 14 \\
2015-2019 & & \\
$3 \quad \begin{array}{l}\text { Perusahaan subsektor perbankan } \\
\text { yang selalu masuk dalam indeks }\end{array}$ & $(5)$ & 9 \\
$\quad$ KOMPAS100 selama 5 tahun \\
$\quad$ berturut-turut sejak tahun 2015-
\end{tabular}

Sumber: Data Penelitian, 2020

Berdasarkan Tabel 2, perusahaan yang menjadi objek penelitian sebanyak 9 (sembilan) perusahaan dihasilkan dari eliminasi perusahaan subsektor perbankan yang lolos kriteria untuk menjadi sampel selama periode 2015-2019. (lampiran).

Tabel 3. Hasil Uji Penelitian

\begin{tabular}{lllcr}
\hline Variabel & Tolerance & VIF & $\mathrm{t}$ & \multicolumn{2}{c}{ Sig. } \\
\hline Inflasi & 0,42 & 2,378 & $-0,864$ & 0,395 \\
Suku Bunga & 0,43 & 2,328 & $-2,608$ & 0,015 \\
PER & 0,285 & 3,504 & $-0,530$ & 0,600 \\
PBV & 0,29 & 3,448 & 1,225 & 0,232 \\
Durbin Watson & 1,927 & & \\
Adjusted R Square & 0,211 & & \\
F- Hit & 3,003 & $0,037 \mathrm{~b}$ & \\
Kolmogorov Smirnov & 0,2 & & \\
\hline
\end{tabular}
Sumber: Data Penelitian, 2020

Tabel 3, menunjukkan bahwa nilai Adjusted R Square adalah 0,211. Artinya perubahan variabel inflasi (X1), suku bunga (X2), PER (variabel kontrol) dan PBV (variabel kontrol) menjelaskan 21,1 persen dari perubahan variabel return saham. Sedangkan 78,9 persen sisanya dijelaskan oleh faktor lain di luar penelitian yang dapat mempengaruhi return saham.

Tabel 3, menunjukkan nilai Fhitung sebesar 3,003 dan nilai efektif 0,037b. Periksa indeks Ftabel dengan memeriksa jumlah sampel $(n)=31$; jumlah variabel $(\mathrm{k})=5$ (lima); tingkat signifikansi $\alpha=0,05 ; \mathrm{df} 1=\mathrm{k}-1=5-1=4$ dan df2 $=\mathrm{nk}=31-5$ $=26$, nilai Ftabel 2.74, jadi Fhitung (3.003)> Ftabel (2.74) dan indikator lainnya adalah nilai efektif (0.037)). b) tingkat signifikansi $<0,05$. Dengan demikian H1 diterima, sehingga dapat dikatakan bahwa variabel inflasi, suku bunga, PER dan PBV secara simultan berpengaruh terhadap return saham.

Hasil uji $\mathrm{t}$ mengenai variabel Inflasi terhadap variabel Return Saham diperoleh thitung $<$ ttabel dimana nilai $-0,864<2,05553$ dan nilai signifikansi sebesar 0,395 dimana 0,395 >0,05. Dengan demikian, secara parsial variabel Inflasi 
berpengaruh negatif tidak signifikan terhadap Return Saham. Inflasi merupakan kecenderungan naiknya harga-harga barang yang beredar di masyarakat. Pada penelitian ini terbukti secara empiris bahwa inflasi tidak berpengaruh terhadap return saham. Hasil uji T menunjukkan pengaruh inflasi terhadap return saham berkorelasi secara negatif, artinya ketika inflasi naik maka dapat dijadikan indikator untuk memprediksi bahwa return saham juga akan turun. Hal ini dipicu karena inflasi yang naik akan membuat investor merasa khawatir akan nilai mata uang yang menurun. Solusi untuk mengimbangi penurunan nilai mata uang tersebut adalah dengan investasi pada instrumen saham terutama subsektor perbankan yang cenderung terpercaya. Semakin banyak investor yang sadar akan hal tersebut maka semakin banyak saham yang dibeli. Akumulasi pembelian membuat harga semakin naik dan akhirnya diikuti oleh peningkatan return saham. hasil penelitian sesuai Adnyana et al. (2017) yang menyimpulkan bahwa variabel inflasi tidak menjadi faktor utama dalam penentu return saham karena dimata investor tingkat inflasi masih wajar.

Hasil uji t mengenai variabel Suku Bunga terhadap variabel Return Saham diperoleh thitung $<$ ttabel dimana nilai $-2,608<2,05553$ dan nilai signifikansi sebesar 0, 15 dimana 0,015<0,05. Dengan demikian, secara parsial variabel Suku Bunga berpengaruh negatif signifikan terhadap Return Saham. Suku bunga pada penelitian adalah bentuk kebijakan moneter Bank Indonesia yang diwujudkan dalam BI 7-Day (Reverse). Pada penelitian ini terbukti secara empiris bahwa suku bunga berpengaruh terhadap return saham, dengan demikian hasi penelitian mendukung teori APT (Arbitrage pricing Theory) yang menjelaskan bahwa return investasi dapat diprediksi menggunakan faktor makroekonomi. Investasi dalam penelitian ini adalah pada instumen saham dan faktor makroekonomi kedua adalah suku bunga, sehingga dalam memprediksi return saham dapat menggunakan indikator suku bunga. Hasil uji T menunjukkan pengaruh suku bunga terhadap return saham berkorelasi secara negatif, artinya ketika suku bunga naik maka dapat dijadikan indikator untuk memprediksi bahwa return saham akan turun. Hal ini karena ketika suku bunga naik investor akan cenderung menarik investasinya pada instrumen saham kemudian menabung di bank untuk mendapatkann keuntungan dari bunga. Kendati saham subsektor perbankan secara prospek menjanjikan, bunga simpanan bank dinilai investor lebih menguntungkan. Penarikan investasi dilakukan dengan menjual saham, kemdian terakumulasi dan menyebabkan harga saham turun diikuti dengan penurunan return saham. Penelitian ini sejalan dengan penelitian yang dilakukan Apriliany \& Effendi (2019) yang menyimpulkan bahwa suku bunga berpengaruh secara negatif dan signfikan terhadap return saham.

Hasil uji t mengenai variabel PER terhadap variabel Return Saham diperoleh thitung $<$ ttabel dimana nilai $-0,530<2,05553$ dan nilai signifikansi sebesar 0,600 dimana 0,600 >0,05. Dengan demikian, secara parsial variabel PER berpengaruh negatif tidak signifikan terhadap Return Saham. PER adalah alternatif yang dapat digunakan investor dalam menilai fundamental perusahaaan dengan memperhitungkan harga dan nilai laba perusahaan. Pada penelitian ini terbukti secara empiris bahwa variabel PER tidak berpengaruh terhadap variabel return saham, artinya PER bukan merupakan indikator utama yang digunakan investor dalam menentukakkan return saham. Hal ini dapat disebabkan karena investor 
menggunakan rasio lain dalam menilai saham, terutama dalam saham subsektor perbankan yang memiliki rasio khusus berkaitan dengan industri perbankan. Selain itu, penelitian ini tidak sejalan dengan penelitian Amalia (2018) yang menyimpulkan bahwa variaebel PER berpengaruh negatif terhadap return saham sehingga setiap kenaikan PER berimplikasi pada penurunan return saham.

Hasil uji t mengenai variabel PBV terhadap variabel Return Saham diperoleh thitung < ttabel dimana nilai 1,225 < 2,05553 dan nilai signifikansi sebesar 0,232 dimana 0,232 >0,05. Dengan demikian, secara parsial variabel PBV berpengaruh tidak signifikan terhadap Return Saham. PBV adalah merupakan alternatif rasio yang dapat digunakan untuk menilai suatu saham, karena secara teoritis nilai pasar suatu saham harus mencerminkan nilai bukunya. Pada penelitian ini terbukti secara empiris bahwa variabel PBV tidak berpengaruh terhadap variabel return saham, artinya PBV bukan merupakan indikator utama yang digunakan investor dalam menentukakkan return saham. Hal ini dapat disebabkan karena investor menggunakan rasio lain dalam menilai saham, terutama dalam saham subsektor perbankan yang memiliki rasio khusus berkaitan dengan industri perbankan. Selain itu, penelitian ini tidak sejalan dengan penelitian Amalia (2018) yang menyimpulkan bahwa variabel PBV berpengaruh positif terhadap return saham sehingga setiap kenaikan PBV akan membuat return saham naik.

\section{SIMPULAN}

Inflasi dan Suku Bunga berpengaruh secara simultan terhadap Return Saham subsektor perbankan dalam indeks KOMPAS100 tahun 2015-2019. Inflasi secara parsial tidak berpengaruh signifikan terhadap Return Saham subsektor perbankan dalam indeks KOMPAS100 tahun 2015-2019. Penelitian ini mendukung penelitian yang dilakukan oleh Adnyana et al. (2019). Penelitian ini menyatakan bahwa inflasi bukan faktor utama yang mempengaruhi return saham karena investor mem\&ang inflasi masih pada tingkat rendah sehingga lebih berfokus pada faktor lain yang berkontribusi terhadap peningkatan return saham. Suku Bunga secara parsial berpengaruh negatif signifikan terhadap Return Saham subsektor perbankan dalam indeks KOMPAS100 tahun 2015-2019. Penelitian ini mendukung penelitian yang dilakukan oleh Apriliany \& Effendi (2019). Penelitian ini menjelaskan bahwa ketika suku bunga naik maka investor akan menarik investasinya pada instrumen saham dan lebih memilih untuk menabung di bank kemudian harga saham turun diikuti dengan penurunan return saham. PER dan PBV sebagai variabel kontrol, secara parsial tidak berpengaruh terhadap Return Saham subsektor perbankan dalam indeks KOMPAS100 tahun 2015-2019.

Variabel yang diteliti dalam penelitian ini terbatas pada variabel inflasi, suku bunga, PER dan PBV. Masih banyak variabel-variabel lain diluar penelitian yang diduga dapat berpengaruh terhadap return saham. Penelitian ini terbatas pada saham subsektor perbankan pada indeks KOMPAS100 saja, sehingga diduga belum cukup mewakili subsektor perbankan secara keseluruhan.

Penelitian selanjutnya dapat menambahkan variabel makro dan variabel fundamental industri perbankan yang mampu mempengaruhi return saham seperti PDB, nilai tukar, BOPO, NPL dan CAR. Untuk penelitian selanjutnya objek penelitian sebaiknya dapat dibuat lebih luas, tidak terbatas pada indeks saja untuk 
mewakili subsektor. Untuk investor dapat menggunakan faktor suku bunga sebagai acuan ketika memprediksi return saham subsektor perbankan.

\section{REFERENSI}

Afiyanti, Hidaya Tri. (2018). Pengaruh Inflasi, BI Rate Dan Nilai Tukar Terhadap Return Saham (Studi Pada Perusahaan Subsektor Food \& Beverages Yang Terdaftar Di Bursa Efek Indonesia Periode 2013-2016). Jurnal Administrasi Bisnis, 61(2), 136-143.

Al-Abdallah, Shadi Yousef. (2017). Influence of Interest Rate, Exchange Rate \& Inflation on Common Stock Returns of Amman Stock Exchange, Jordan. International Journal of Economics, Commerce \& Management, 5, 589-601.

Al Oshaibat, Suleiman, \& Ahmad Majali. (2016). The Relationship between Stock Returns \& Each of Inflation, Interest Rates, Share Liquidity \& Remittances of Workers in the Amman Stock Exchange. The Journal of Internet Banking \& Commerce, 21(2).

Assagaf, Aminullah, Etty Murwaningsari, Juniati Gunawan, \& Sekar Mayangsari. (2019). The Effect of Macro Economic Variables on Stock Return of Companies That Listed in Stock Exchange: Empirical Evidence from Indonesia. International Journal of Business \& Management, 14(8) doi: 10.5539/ijbm.v14n8p108.

Balagobei, Saseela. (2017). Macroeconomic Variables \& Stock Market Returns in Sri Lanka. Asian Journal of Finance \& Accounting 9(2), 206. doi: 10.5296/ajfa.v9i2.11832.

Denziana, Angrita, Haninun, \& Hepiana Patmarina. (2015). The International Multidisciplinary Conference on Social Sciences, 1, 73. doi: 10.1017/CBO9781107415324.004.

Dwialesi, Juanita, \& Ni Darmayanti. (2016). Pengaruh Faktor-Faktor Fundamental Terhadap Return Saham Indeks KOMPAS100. E-Jurnal Manajemen Universitas Udayana, 5(9), 5369-5397.

Eldomiaty, Tarek, Yasmeen Saeed, Rasha Hammam, \& Salma AboulSoud. (2019). The Associations between Stock Prices, Inflation Rates, Interest Rates Are Still Persistent: Empirical Evidence from Stock Duration Model. Journal of Economics, Finance \& Administrative Science, 25(49), 149-162. doi: 10.1108/JEFAS-10-2018-0105.

Gusni, Gusni, \& Suskim Riantani. (2017). Penggunaan Arbitrage Pricing Theory Untuk Menganalisis Return Saham Syariah. Jurnal Manajemen, 9(1), 68-84. doi: $10.31937 /$ manajemen.v9i1.598.

Iqmal, Fariz Mohamad, \& Ivan Gumilar Sambas Putra. (2020). Macroeconomic Factors \& Influence on Stock Return That Impact the Corporate Values. International Journal of Finance \& Banking Studies (2147-4486), 9(1), 68-75. doi: 10.20525/ijfbs.v9i1.667.

Jamaludin, Nurasyikin, Shahnaz Ismail, \& Syamimi Ab Manaf. (2017). International Journal of Economics \& Financial Issues Macroeconomic Variables \& Stock Market Returns: Panel Analysis from Selected ASEAN Countries. International Journal of Economics \& Financial Issues, 7(1), 37-45.

Kurniasari, Wulan, Adi Wiratno, \& Muhammad Yusuf. (2018). Pengaruh Inflasi Dan Suku Bunga Terhadap Return Saham Dengan Profitabilitas Sebagai 
Variabel Intervening Di Perbankan Yang Terdaftar Di Bursa Efek Indonesia Tahun 2013-2015. Journal of Accounting Science, 2(1), 67-90. doi: 10.21070/jas.v2i1.1216.

Nofitasari, Oki, \& Augustina Kurniasih. (2020). The Influences of Company's Internal Factors \& Macroeconomics against the Stock Return from the Construction, Property \& Real Estate Sectors Registered on Indonesia Stock Exchange, 5, 129-139.

Novitasari, Ni Luh Gede. (2017). Pengaruh Corporate Governance Dan Faktor Fundamental Terhadap Return Saham Pada Perusahaan Manufaktur Yang Terdaftar Di Bursa Efek Indonesia. KRISNA: Kumpulan Riset Akuntansi, 9(1), 36-49.

Sangmi, Mohi. (2013). Macroeconomic Variables on Stock Market Interactions: The Indian Experience. IOSR Journal of Business \& Management, 11(3), 15-28. doi: 10.9790/487X-01131528.

Saputra, I. S. D., \& Wardoyo. (2019). Analysis of The Effect of Return on Assets, Earning per Share, Inflation Rate, \& Interest Rate on Stock Return: A Case Study of SOE Banking Companies Listed in Indonesia Stock Exchange.. Russian Journal of Agricultural \& Socio-Economic Sciences, 85(1), 24-34. doi: 10.18551/rjoas.2019-01.03.

Siregar, Citra Putri Septanti, Hermanto, \& Hendro Sasongko. (2016). Analysis the Impact of Macroeconomic on Financial Performance \& Stock Returns of StateOwned Banks in Indonesia Stock Exchange 2006-2016. International Journal of Science \& Research, 5(12), 212-217. doi: 10.21275/ ART20163351.

Suriyani, Ni Kadek, \& Gede Mertha Sudiartha. (2018). Pengaruh Tingkat Suku Bunga, Inflasi dan Nilai Tukar terhadap Return Saham di Bursa Efek Indonesia. E-Jurnal Manajemen Universitas Udayana, 7(6). doi: 10.24843/EJMUNUD.2018.v07.i06.p12.

Wijayanti, Delia, \& Sishadiyati. (2020). Analisis Suku Bunga, Kurs dan Inflasi terhadap Return Saham Blue Chip Sektor Perbankan. Jurnal Dinamika Ekonomi Pembangunan, 3(1), 276-281.

Wiradharma A, Made, \& Luh Sudjarni. (2016). Pengaruh Tingkat Suku Bunga, Tingkat Inflasi, Nilai Kurs Rupiah dan Produk Domestik Bruto terhadap Return Saham. E-Jurnal Manajemen Universitas Udayana, 5(6).

Yunita, Y., \& Robiyanto, R. (2018). The Influence Of Inflation Rate, Bi Rate, \& Exchange Rate Changes To The Financial Sector Stock Price Index Return In The Indonesian Stock Market. Jurnal Manajemen dan Kewirausahaan, 20(2), 8086. doi: $10.9744 / j m k .20 .2 .80-86$.

Yusfiarto, R. (2020). Micro Macro Economics Fundamental Factors \& Indonesia Stock Exchange Return. EkBis: Jurnal Ekonomi dan Bisnis, 3(1), 221-231. doi: 10.14421/ekbis.2019.3.1.1183.

Zaini, Virza Ilham, Isfenti Sadalia, \& Khaira Amalia Fachrudin. (2018). The Effect of External \& Internal Factors on Stock Return with Price to Book Value as Moderation Variables in Banking Companies in Indonesia Stock Exchange. International Journal of Scientific \& Technology Research, 7(9), 1-10. 